\title{
EFFECTS OF EXPOSURE TO MIXED ORGANIC SOLVENTS ON BLOOD PRESSURE IN NON-SMOKING WOMEN WORKING IN A PHARMACEUTICAL COMPANY
}

\author{
Saber MOHAMMADI, Majid GOLABADI, Yasser LABBAFINEJAD, Fatemeh PISHGAH- \\ HADIAN, and Mirsaeed ATTARCHI
}

Occupational Medicine Department, School of Medicine, Tehran University of Medical Sciences, Tehran, Iran

Received in December 2011

CrossChecked in December 2011

Accepted in March 2012

\begin{abstract}
Some studies suggest that exposure to industrial solvents can affect blood pressure. The objective of this study was to investigate the effect of a mixture of organic solvents on blood pressure in women working in a pharmaceutical company in Iran. Four hundred and thirty-three women were included in the study. Women working in packing units (group 1) were not exposed to the mixture of organic solvents, women in new laboratory units (group 2) were exposed to the mixture within the permitted range and women working in old laboratory units (group 3) were exposed to the mixture above the permitted limit. We compared systolic and diastolic blood pressures (SBP \& DBP) and prevalence of hypertension and prehypertension among groups. The results revealed a significant difference in SBP and pre-hypertension $(p<0.001)$ and hypertension $(p<0.05)$ prevalence between the exposed and the control group, but DBP did not differ significantly. Logistic regression analysis showed a significant association between hypertension and exposure to mixed solvents. Odds ratio for hypertension in the group 2 and group 3 (exposed) workers was 2.36 and 3, respectively, compared to controls. Our results suggest that exposure to a mixture of organic solvents may increase SBP and hypertension and pre-hypertension prevalence in drug manufacture workers. Therefore, more attention should be paid to workers that work in such settings by periodically measuring blood pressure and implementing accurate and comprehensive programs to reduce exposure to organic solvents.
\end{abstract}

KEY WORDS: hypertension, industrial solvents, occupational exposure

According to the Seventh Report of the Joint National Committee on Hypertension of 2003, hypertension was a major public health concern affecting about 50 million people in the USA and about one billion people all over the world (1). Hypertension is still a serious public health concern and is a major risk factor for heart failure, myocardial infarction, and some cerebrovascular diseases such as stroke (2). Therefore, priority should be given to the recognition, treatment, and control of this public health problem (3).

Organic solvents are frequently used in the production of dyes, plastic and rubber, and in the printing industry (4). According to NIOSH (National Institute for Occupational Safety and Health), 9.8 million American workers were exposed to solvents in the first half of the 1970s (4). A number of studies have shown that organic solvents are associated with 
auditory (5), visual (6), cardiovascular (7), neurological (8), and other complications (9-11). Some suggested that chronic exposure to industrial solvents can affect blood pressure (12-16). Bener et al. (13) investigated the prevalence of hypertension among workers who were exposed to gasoline vapour in their workplace; $71.4 \%$ of the exposed group and $28.6 \%$ of the control group had taken medications for the treatment of hypertension, and the difference was statistically significant $(\mathrm{p}<0.001)$. The $90^{\text {th }}$ percentile of systolic blood pressure in the exposed group was 140 whereas in the control group it was 130. In a study by Kotseva et al. (7) occupational exposure to high levels of xylene and benzene increased the prevalence of hypertension in workers. In a study by Mørck et al. (17), a significant rise in systolic blood pressure was found among workers occupationally exposed to toluene. After six weeks without exposure, systolic blood pressure decreased. However, other studies found an insignificant increase in blood pressure in workers exposed to mixed organic solvents compared to control $(18,19)$.

The exact mechanism of the effect of solvents on blood pressure is still unclear. In a study on rats, Sun et al. (20) examined endothelial nitric oxide synthase (eNOS) activity and blood pressure level following exposure to trinitrotoluene (TNT). They found that TNT inhibited eNOS activity and increased systolic blood pressure (20).

Evaluating exposure to a single organic solvent is rather difficult because workers are normally exposed to varying concentrations of mixtures of organic solvents over different time spans (21). However, there are only a few studies on the relation between mixture of solvents and blood pressure.

The pharmaceutical industry employs more than 350 thousand people all over the world in various operations including marketing, sales, manufacturing, and research and development. People most likely to be exposed to drug substances and chemical precursors in their occupational setting are those working in research and development and manufacturing (22). Solvent use is common in pharmaceutical industry and consistently accounts for between $80 \%$ and $90 \%$ of mass utilisation in a typical pharmaceutical batch chemical operation (23).

The objective of the present study was to examine the effect of a mixture of organic solvents on blood pressure in women working in a pharmaceutical company.

\section{MATERIALS AND METHODS}

\section{Study design and subjects}

We conducted a cross-sectional study in a pharmaceutical plant in Iran during 2010-2011. It included all workers with at least one year of working experience in the company, 449 in total. All the workers were women. From the records and interviews we gathered the following data for all of them: age, length of service, work schedule, second or previous occupation, personal habits, regular exercise, cigarette smoking, tea and salt consumption habits, systemic disease history (such as diabetes mellitus, cardiac or renal diseases), family history of hypertension and drug history. Regular exercise was defined as at least half an hour of physical activity three or more times a week (24). Responses to the question on dietary salt were classified into three groups: low intake (lower than usual: no adding salt when cooking), moderate intake (usual: no adding salt when eating) and high intake (more than usual: adding salt when eating). Work schedule was divided into shift work and day work. Fixed day shift was considered day work, and other schedules were considered shift work (25).

Exclusion criteria were pre-employment history of hypertension or known chronic illnesses such as diabetes mellitus, cardiovascular and cerebrovascular diseases and exposure to organic solvents in past jobs, second jobs or because of personal habits (26). After applying these criteria, 16 women were excluded and 433 remained in the study: 212 in packing units (group 1 - unexposed controls), 146 in new laboratory units (group 2 - low exposure), and 75 in old laboratory units (group 3 - high-exposure). All women participated voluntarily and signed the informed consent form. The study was approved by the ethics committee of Tehran University of Medical Sciences.

All workers were interviewed and examined by an occupational medicine physician.

Blood was collected and blood pressure measured under fasting conditions between 8:00 and 9:00 am, just before starting work. Blood pressure was taken with each subject sitting on a chair after at least five minutes of rest.

Systolic and diastolic blood pressure (SBP and DBP, respectively) were measured twice in the right arm, using a standard mercury sphygmomanometer. The mean value of the two blood pressure measurements was used for this study. We defined hypertensive 
subjects as those who reported diagnosed hypertension or those whose mean resting SBP and resting DBP were $\geq 140 \mathrm{~mm} \mathrm{Hg}$ and $\geq 90 \mathrm{~mm} \mathrm{Hg}$, respectively. Pre-hypertension was defined as mean resting SBP between $120 \mathrm{~mm} \mathrm{Hg}$ and $139 \mathrm{~mm} \mathrm{Hg}$ or mean resting DBP between $80 \mathrm{~mm} \mathrm{Hg}$ and $89 \mathrm{~mm} \mathrm{Hg}$. Furthermore, for each subject, we measured fasting blood sugar (FBS), lipid profile including cholesterol, triglycerides, low-density lipoprotein (LDL) and high-density lipoprotein (HDL), as well as liver function including alanine transaminase (ALT), aspartate aminotransferase (AST), and alkaline phosphatase (ALP). Workers' heights and weights were used to calculate body mass index (BMI).

\section{Exposure assessment}

The company's occupational hygiene team performed air monitoring for all existing solvents in the working environment. In order to determine solvent exposure in each location, the team also performed an analysis of workplaces and identified a set of job descriptions for each workplace. All eighthour time-weighted measurement averages were based on environmental sampling for each workplace. Air was monitored continuously over the eight hour shift. Air samples were collected on charcoal tubes with constant flow (100 $\mathrm{mL} \mathrm{min}^{-1}$ ) pumps (SKC 226-01, Gulf Coast Inc., USA) at 42 stations designed for the new laboratory units, 29 stations designed for the old laboratory units and 36 stations designed for the packing units. According to the NIOSH analytical method 1501 for aromatic hydrocarbons, the charcoal tubes were located at a height of $1.5 \mathrm{~m}$ (27). Subsequently, gas chromatography (Hewlett-Packard 5890, Avondale, PA, USA) was used to analyse the samples and the average concentration of each solvent was identified.

The solvents present in all laboratory units of the factory were toluene, xylene, formaldehyde, phenol, n-hexane, and chloroform.

The American Conference of Governmental Industrial Hygienists (ACGIH) equation was used to evaluate occupational exposure of workers to the organic solvents mixture (28).

$$
\mathrm{E}_{\mathrm{m}}=\mathrm{C}_{1} / \mathrm{L}_{1}+\mathrm{C}_{2} / \mathrm{L}_{2}+\ldots .+\mathrm{C}_{\mathrm{n}} / \mathrm{L}_{\mathrm{n}}
$$

where $E_{m}$ is the equivalent exposure for the organic solvents mixture, $\mathrm{C}$ is the mean concentration level of organic solvents in the air of the workstation, and $\mathrm{L}$ is the exposure limit for organic solvents. In this equation, $\mathrm{E}_{\mathrm{m}}$ above 1 indicates that the level of organic solvent mixture in the workplace is higher than the permissible limit (28). Since the equation of mixed organic solvents can only be used for solvents with identical adverse effects on target organs or systems, we only inserted solvents with similar adverse effects on cardiovascular system into the equation; these organic solvents were toluene, xylene and phenol.

Mean concentrations of toluene, xylene, and phenol in new laboratory units were $12.3 \mathrm{mg} \mathrm{m}^{-3}$, $53 \mathrm{mg} \mathrm{m}^{-3}$, and $0.98 \mathrm{mg} \mathrm{m}^{-3}$, respectively, and the concentrations in old laboratory units were $90 \mathrm{mg}$ $\mathrm{m}^{-3}, 278 \mathrm{mg} \mathrm{m}^{-3}$, and $1.99 \mathrm{mg} \mathrm{m}^{-3}$, respectively. The exposure limit for toluene, xylene and phenol is $192 \mathrm{mg} \mathrm{m}^{-3}, 442 \mathrm{mg} \mathrm{m}^{-3}$, and $19.6 \mathrm{mg} \mathrm{m}^{-3}$, respectively.

In the high-exposure group (old laboratory units), $\mathrm{E}_{\mathrm{m}}$ ranged from 1.094 to 2.820 and its median value was 1.202 . In the low-exposure group (new laboratory units), $\mathrm{E}_{\mathrm{m}}$ was between 0.183 and 0.631 and its median value was 0.234 . $\mathrm{E}_{\mathrm{m}}$ values indicated that the concentration of mixed organic solvents in old laboratory units was above the permitted limit whereas in new laboratory units it was within the permitted range.

Finally, in the non-exposure group (packing units) the concentrations of organic solvents were negligible.

\section{Statistical analysis}

We calculated mean, range and standard deviation (SD) of quantitative variables and used ANOVA to compare these variables between the groups. Chisquare was used to compare qualitative variables. Logistic regression analysis with confounding variables eliminated was used to establish the correlation between hypertension and exposure to mixed organic solvents. Continuous variables of age, length of service and body mass index were categorised based on the median of each variable. The level of significance was set at $\mathrm{p}<0.05$. We also used odds ratio (OR) with $95 \%$ confidence intervals (95\% CI) to express the results of our analysis. All study variables were analysed using SPSS 11 software.

\section{RESULTS}

We evaluated 433 women working in a drug manufacturing plant. The workers' mean age was 31.72 years, range (22 to 55 ) years. Their average 
Table 1 Demographic variables and risk factors for hypertension in study groups

\begin{tabular}{lcccc}
\hline Variable & $\begin{array}{c}\text { Unexposed (control) } \\
\text { group (N=212) }\end{array}$ & $\begin{array}{c}\text { Low-exposure } \\
\text { group (N=146) }\end{array}$ & $\begin{array}{c}\text { High-exposure } \\
\text { group (N=75) }\end{array}$ & p-value \\
\hline${ }^{\mathrm{a}}$ Age / year & $32.3 \pm 4.6$ & $31.6 \pm 5.1$ & $30.5 \pm 5.8$ & 0.049 \\
\hline${ }^{\mathrm{a}}$ Length of service / year & $9.5 \pm 5.4$ & $8.7 \pm 5.0$ & $7.9 \pm 4.8$ & 0.051 \\
\hline${ }^{\mathrm{a} B o d y ~ m a s s ~ i n d e x ~ / ~ k g ~ m ~}{ }^{-2}$ & $24.1 \pm 3.3$ & $23.5 \pm 3.5$ & $23.0 \pm 3.4$ & 0.065 \\
\hline${ }^{\mathrm{b}}$ Tea consumption / Yes & $132(62.2)$ & $87(59.5)$ & $45(60.0)$ & 0.923 \\
\hline${ }^{\mathrm{b} D i e t a r y ~ s a l t ~}$ & $103(48.6)$ & $85(58.2)$ & $39(52.0)$ & 0.365 \\
Low & $77(36.3)$ & $39(26.7)$ & $24(32.0)$ & $12(16.0)$ \\
Moderate & $32(15.1)$ & $22(15.1)$ & $11(14.6)$ & 0.881 \\
High & $36(16.9)$ & $25(17.1)$ & $16(21.3)$ & 0.914 \\
\hline${ }^{\mathrm{b}}$ Regular exercise / Yes & $46(21.6)$ & $31(21.2)$ & $5(6.6)$ & 0.992 \\
\hline${ }^{\mathrm{b}}$ Shift work / Yes & $15(7.0)$ & $10(6.8)$ & & \\
\hline $\begin{array}{l}{ }^{\mathrm{b}} \text { Family history of } \\
\text { hypertension / Yes }\end{array}$ & & & & \\
\hline
\end{tabular}

${ }^{a}$ Data are expressed as mean $\pm S D$

${ }^{b}$ Data are expressed as number of persons and percent of $N$

Table 2 Prevalence of hypertension and pre-hypertension and mean $S B P^{*} \& D B P^{* *}$ in studied groups

\begin{tabular}{lcccc}
\hline Study groups & $\begin{array}{c}\text { SBP } / \mathbf{~ m m ~ H g} \\
\text { Mean } \pm \text { SD }\end{array}$ & $\begin{array}{c}\text { DBP } / \mathbf{~ m m ~ H g} \\
\text { Mean } \pm \text { SD }\end{array}$ & $\begin{array}{c}\text { Hypertension } \\
\mathbf{n}(\%)\end{array}$ & $\begin{array}{c}\text { Pre-hypertension } \\
\mathbf{n}(\%)\end{array}$ \\
\hline $\begin{array}{l}\text { Non-exposure group } \\
(\mathrm{N}=212)\end{array}$ & $125.1 \pm 14.0$ & $75.6 \pm 12.6$ & $18(8.4)$ & $34(16.0)$ \\
\hline $\begin{array}{l}\text { Low-exposure group } \\
(\mathrm{N}=146)\end{array}$ & $127.5 \pm 15.7$ & $77.5 \pm 13.8$ & $21(14.3)$ & $67(45.8)$ \\
\hline $\begin{array}{l}\text { High-exposure group } \\
(\mathrm{N}=75)\end{array}$ & $133.9 \pm 9.7$ & $79.2 \pm 13.3$ & $14(18.6)$ & $39(52.0)$ \\
\hline p-value & $<0.001$ & 0.145 & 0.024 & $<0.001$ \\
\hline
\end{tabular}

* Systolic blood pressure

${ }^{* *}$ Diastolic blood pressure

$n=$ number of persons

length of service was 9.04 years, range (1 to 26) years and average BMI was $23.75 \mathrm{~kg} \mathrm{~m}^{-2}$, range (17.21 to $32.14) \mathrm{kg} \mathrm{m}^{-2}$. In our study, 93 workers $(21.5 \%)$ were shift workers. Table 1 summarises the demographic variables and potential risk factors for the study groups. There were no statistically significant differences between the groups in the length of service, body mass index, tea consumption, dietary salt, regular exercise, shift work, and family history of hypertension. However, the mean age was higher in group 1 $(p<0.05)$. There were no statistically significant differences between the groups in FBS, lipid profiles (cholesterol, triglycerides, LDL and HDL), and liver function tests (ALT, AST and ALP).

Mean resting SBP and DBP were $127.28 \mathrm{~mm} \mathrm{Hg}$, range (90 to 160$) \mathrm{mm} \mathrm{Hg}$ and $76.27 \mathrm{~mm} \mathrm{Hg}$, range (50 to 110$) \mathrm{mm} \mathrm{Hg}$, respectively. Fifty-three (12.2\%) workers were hypertensive and 140 (32.3\%) pre- hypertensive. Table 2 shows mean SBP and DBP and hypertension and pre-hypertension prevalence in the studied groups. There was a significant difference between the control group and groups 2 and 3 in SBP and prevalence of pre-hypertension $(\mathrm{p}<0.001)$ and hypertension $(p<0.05)$, but there was no significant difference in DBP (Table 2). The difference between groups 2 and 3 was only significant in terms of SBP $(\mathrm{p}<0.05)$.

Logistic regression analysis with adjustment of confounding variables showed that occupational solvents exposure was significantly associated with high blood pressure $(\mathrm{p}<0.05)$. Compared to the unexposed group, the odds ratio (OR) for hypertension was 3.00 in the group that was exposed to a higher than the permitted level, and it was 2.36 in the group that was exposed to the permitted range (Table 3 ). 
In this study, there was a significant association between hypertension and variables such as age, high dietary salt intake, length of service, BMI, regular exercise, and shift work $(\mathrm{p}<0.05)$, but there was no association between hypertension and family history of hypertension (Table 3).

\section{DISCUSSION}

Our findings suggest that exposure to mixed organic solvents can affect blood pressure. Lowexposure and high-exposure groups have significantly elevated odds ratios for hypertension. No group differed in the length of service, smoking, BMI, and other variables, except average age, which was higher in the control group. Therefore, the correlation between hypertension and exposure to a mixture of organic solvents was not affected by the above mentioned confounding factors.

We observed significantly higher mean SBP between workers with high exposure and low exposure to mixed organic solvents, $8.8 \mathrm{~mm} \mathrm{Hg}$ and $2.4 \mathrm{~mm} \mathrm{Hg}$ respectively, compared to the control group.

Gericke et al. (29) studied a group of printers who had been exposed to toluene for more than 20 years and found that chronic exposure to toluene can increase SBP. However, this study did not consider many probable confounders.

In our study, DBP was higher in groups 2 and 3 than in the control group, but this difference was not significant. In a study by Egeland et al. (16) involving 410 male textile workers, 165 of whom were exposed and 245 not exposed to carbon disulphide $\left(\mathrm{CS}_{2}\right)$, SPB was not affected by exposure but diastolic blood pressure was. Kaukiainen et al. (12) studied 26 workers with chronic exposure to organic solvents and 19 unexposed volunteer workers. After adjusting for confounding factors such as age, sex, alcohol consumption, cigarette smoking, and BMI, SBP turned out to be significantly higher in the exposed workers, suggesting that lifetime exposure to organic solvents can increase systolic blood pressure.

In our study, the prevalence of pre-hypertension and hypertension was significantly higher in the exposed groups (2 and 3 ) compared to the control group.

Regression analysis with eliminating confounding factors confirmed the correlation between hypertension and exposure to a mixture of solvents. Compared to the group with no exposure, the odds ratio (OR) for hypertension was 3.00 in the group with exposure above the permitted level, and 2.36 in the group with exposure within the permitted range.

Table 3 Relationship between hypertension and study variables using logistic regression analysis

\begin{tabular}{|c|c|c|c|c|}
\hline Variable & Status & Adjusted OR & $95 \% \mathrm{CI}$ & p-value \\
\hline \multirow{3}{*}{ Study groups } & Non-exposure $(\mathrm{N}=212)$ & 1.00 & ----------- & ----- \\
\hline & Low-exposure $(\mathrm{N}=146)$ & 2.36 & $1.14-4.82$ & 0.021 \\
\hline & High-exposure $(\mathrm{N}=75)$ & 3.00 & $1.30-6.91$ & 0.010 \\
\hline \multirow{2}{*}{ Age / year } & $\leq 31(\mathrm{n}=223)$ & 1.00 & ---------- & ------- \\
\hline & $>31(n=210)$ & 2.99 & $1.24-6.86$ & 0.035 \\
\hline \multirow{2}{*}{ Length of service / year } & $\leq 9(n=207)$ & 1.00 & ----------- & ------- \\
\hline & $>9(n=226)$ & 2.54 & $1.07-6.09$ & 0.034 \\
\hline \multirow{2}{*}{ Body mass index $/ \mathrm{kg} \mathrm{m}^{-2}$} & $\leq 23.4(\mathrm{n}=214)$ & 1.00 & ----------- & ------- \\
\hline & $>23.4(\mathrm{n}=219)$ & 2.03 & $1.04-3.96$ & 0.038 \\
\hline \multirow[t]{3}{*}{ Dietary salt } & Low $(n=227)$ & 1.00 & ---------- & ------ \\
\hline & Moderate $(n=140)$ & 2.41 & $1.06-4.99$ & 0.047 \\
\hline & High $(n=66)$ & 3.35 & $1.46-7.70$ & 0.004 \\
\hline \multirow{2}{*}{ Regular exercise } & $\operatorname{Yes}(n=72)$ & 1.00 & ----------- & ------- \\
\hline & $\operatorname{No}(n=361)$ & 4.33 & $1.27-14.77$ & 0.019 \\
\hline \multirow{2}{*}{ Shift work } & No $(n=93)$ & 1.00 & ---------- & ------- \\
\hline & Yes $(n=340)$ & 2.83 & $1.18-5.71$ & 0.033 \\
\hline \multirow{2}{*}{$\begin{array}{l}\text { Family history of } \\
\text { hypertension }\end{array}$} & No $(n=403)$ & 1.00 & ----------- & ------- \\
\hline & Yes $(n=30)$ & 1.48 & $0.40-5.41$ & 0.551 \\
\hline
\end{tabular}


In another study, Kaukiainen et al. (14) investigated the prevalence of symptoms related to solvent exposure among building painters and found that chronic exposure was associated with hypertension and arrhythmia.

In a study by Wiwanitkit (15), the prevalence of hypertension was significantly higher in the group with high levels of benzene exposure (100\%) than in the group with lower levels of benzene exposure (49\%). This study suggests that disturbance of the nitric oxide process may account for benzene-induced hypertension.

Chang et al. (19) studied 20 workers in a synthetic leather manufacturing company to see if there was an association between hypertension and co-exposure to $\mathrm{N}, \mathrm{N}$-dimethylformamide, toluene and noise. They found no significant difference in ambulatory blood pressure between solvent-exposed workers, noiseexposed workers, and workers to this combination compared to the low-exposure group.

Some solvents are associated with cardiovascular diseases (30-32); for example, methylene chloride, styrene and carbon disulfide with coronary artery disease (CAD) and fluorocarbons and tricholoroethane with cardiac arrhythmia. Benzene and xylene have been associated with arterial hypertension (7), and solvent exposure with hypertension in pregnancy $(10$, 33). According to the study by Xiao and Levin (31), exposure to solvents can cause neurotoxic and neuropsychiatric symptoms and sleep disturbance. This can lead to increased personal stress, which, in turn, can affect blood pressure. Disturbance of the nitric oxide process is the likely mechanism triggering hypertension $(15,20)$. Using animal models, Leong et al. (34) showed that $50 \mu \mathrm{L}$ of $10 \%$ phenol injected into the renal cortex of rats may lead to acute hypertension because of the renal sympathetic nerve activation.

In our study, we found an association between hypertension and variables such as age, length of service, BMI, dietary salt, regular exercise, and shift work (Table 3). These findings are similar to the results reported in some earlier studies (26, 35-36).

In our study, the odds ratio for hypertension in shift workers was significantly higher than in daytime workers. Nazri et al. (26) investigated the relationship between shift work and hypertension in workers in a semiconductor manufacturing company. In that study, the prevalence of hypertension among shift workers was significantly higher compared to day workers.
In our study, the odds ratio for hypertension in workers with higher BMI and in workers with irregular physical activity was higher than in the control group. Leung et al. (35) conducted a study among 6193 Chinese students to determine the prevalence and patterns of hypertension. They have suggested that obesity is a predictor of hypertension, while physical activity is a protective factor.

We found that the prevalence of hypertension in workers with moderate and high dietary salt intake was significantly higher than in workers with low dietary salt intake. Cook et al. (36) investigated the effect of a training and consultation program for reducing dietary salt intake on cardiovascular diseases. The results of this study showed that sodium reduction may lead to blood pressure decrease.

Pharmacologically active agents used in pharmaceutical plants can cause adverse health effects, unless occupational exposure is controlled enough (37). Pharmaceutical workers are potentially at risk for occupational asthma, pharmacological effects, adverse reproductive outcomes, dermatitis, and other adverse health effects (22).

This study may have some limitations. First, a cross-sectional design may restrict causal relations. This can be addressed in a prospective cohort study. Another limitation is that in evaluating solvent exposure we relied on environmental monitoring alone. Workers were in separate working environments, which facilitated group classification and exposure assessment, but further studies should consider using biological monitoring instead. Besides, we were not able to calculate cumulative occupational exposure because the information on previous levels of exposure was not available.

We investigated the effects of mixed organic solvents on hypertension, but not the effects of single solvents. However, organic solvent mixtures are more common in workplaces.

\section{CONCLUSION}

Our study suggests that exposure to organic solvent mixtures may increase the prevalence of hypertension and pre-hypertension in drug manufacturing workers. Therefore, more attention should be paid to workers that work in such settings by periodically measuring blood pressure and implementing accurate and comprehensive programmes to reduce exposure to organic solvents. 


\section{REFERENCES}

1. Chobanian AV, Bakris GL, Black HR, Cushman WC, Green LA, Izzo JL Jr, Jones DW, Materson BJ, Oparil S, Wright JT Jr, Roccella EJ; National Heart, Lung, and Blood Institute Joint National Committee on Prevention, Detection, Evaluation, and Treatment of High Blood Pressure; National High Blood Pressure Education Program Coordinating Committee. The Seventh Report of the Joint National Committee on Prevention, Detection, Evaluation, and Treatment of High Blood Pressure: the JNC 7 report. JAMA 2003;289:2560-72.

2. Cohen JD. Hypertension epidemiology and economic burden: refining risk assessment to lower costs. Managed Care 2009;18:51-8.

3. Kearney PM, Whelton M, Reynolds K, Muntner P, Whelton PK, He J. Global burden of hypertension: analysis of worldwide data. Lancet 2005;365:217-23.

4. Rosenstock L, Cullen MR, Brodkin CR, Redlich CA, editors. Textbook of Clinical Occupational and Environmental Medicine. $2^{\text {nd }}$ ed. Philadelphia: Elsevier Saunders; 2004.

5. Fuente A, McPherson B. Central auditory damage induced by solvent exposure. Int J Occup Saf Ergon 2007;13:3917.

6. Attarchi MS, Labbafinejad Y, Mohammadi S. Occupational exposure to different levels of mixed organic solvents and colour vision impairment. Neurotoxicol Teratol 2010;32:55862.

7. Kotseva K, Popov T. Study of the cardiovascular effects of occupational exposure to organic solvents. Int Arch Occup Environ Health 1998;71(Suppl):S87-91.

8. Edling C, Ekberg K, Ahlborg G Jr, Alexandersson R, Barregård L, Ekenvall L, Nilsson L, Svensson BG. Long-term follow up of workers exposed to solvents. Br J Ind Med 1990;47:75-82

9. Baker EL. A review of recent research on health effects of human occupational exposure to organic solvents: a critical review. J Occup Med 1994;36:1079-92.

10. Eskenazi B, Bracken MB, Holford TR, Grady J. Exposure to organic solvents and hypertensive disorders of pregnancy. Am J Ind Med 1988;14:177-88.

11. Attarchi MS, Ashouri M, Labbafinejad Y, Mohammadi S. Assessment of time to pregnancy and spontaneous abortion status following occupational exposure to organic solvents mixture. Int Arch Occup Environ Health 2012;85:295-303.

12. Kaukiainen A, Martikainen R, Luoma K, Taskinen H, Helin $\mathrm{K}$, Vehmas T. Effect of industrial solvent exposure on blood pressure and liver ultrasound echogenicity. Scand J Work Environ Health 2006;32(Suppl 2):54-60.

13. Bener A, Gomes J, Hamouda MFB. Hypertension among workers occupationally exposed to hydrocarbons and organic solvents. J Environ Sci Health A Environ Sci Engin Toxicol 1996;31:291-303.

14. Kaukiainen A, Riala R, Martikainen R, Akila R, Reijula K, Sainio M. Solvent-related health effects among construction painters with decreasing exposure. Am J Ind Med 2004;46:62736.

15. Wiwanitkit V. Benzene exposure and hypertension: an observation. Cardiovasc J Afr 2007;18:264-5.

16. Egeland GM, Burkhart GA, Schnorr TM, Hornung RW, Fajen JM, Lee ST. Effects of exposure to carbon disulphide on low density lipoprotein cholesterol concentration and diastolic blood pressure. Br J Ind Med 1992;49:287-93.

17. Mørck HI, Winkel P, Gyntelberg F. Health effects of toluene exposure. Dan Med Bull 1988;35:196-200.

18. Chang TY, Wang VS, Hwang BF, Yen HY, Lai JS, Liu CS, Lin SY. Effects of co-exposure to noise and mixture of organic solvents on blood pressure. J Occup Health 2009;51:332-9.

19. Chang TY, Wang VS, Lin SY, Yen HY, Lai JS, Liu CS. Coexposure to noise, N,N-dimethylformamide, and toluene on 24-hour ambulatory blood pressure in synthetic leather workers. J Occup Environ Hyg 2010;7:14-22.

20. Sun Y, Iemitsu M, Shimojo N, Miyauchi T, Amamiya M, Sumi D, Hayashi T, Sun G, Shimojo N, Kumagai Y. 2,4,6Trinitrotoluene inhibits endothelial nitric oxide synthase activity and elevates blood pressure in rats. Arch Toxicol 2005;79:705-10.

21. Sliwinska-Kowalska M, Zamyslowska-Szmytke E, Szymczak W, Kotylo P, Fiszer M, Wesolowski W, PawlaczykLuszczynska M, Bak M, Gajda-Szadkowska A. Effects of coexposure to noise and mixture of organic solvents on hearing in dockyard workers. J Occup Environ Med 2004;46:30-8.

22. Binks SP. Occupational toxicology and the control of exposure to pharmaceutical agents at work. Occup Med 2003;53:363-70

23. Constable DJC, Jimenez-Gonzalez C, Henderson RK. Perspective on solvent use in the pharmaceutical industry. Org Process Res Dev 2007;11:133-7.

24. Lee JH, Kang W, Yaang SR, Choy N, Lee CR. Cohort study for the effect of chronic noise exposure on blood pressure among male workers in Busan, Korea. Am J Ind Med 2009;52:509-17.

25. Kivimäki $M$, Virtanen $M$, Elovainio $M$, Väänänen $A$, Keltikangas-Järvinen L, Vahtera J. Prevalent cardiovascular disease, risk factors and selection out of shift work. Scand J Work Environ Health 2006;32:204-8.

26. Nazri S, Tengku M, Winn T. The association of shift work and hypertension among male factory workers in Kota Bharu, Kelantan, Malaysia. Southeast Asian J Trop Med Public Health 2008;39:176-83.

27. National Institute for Occupational Safety and Health (NIOSH). Hydrocarbons, aromatic: Method 1501, Issue 3. 2003 [displayed 3 May 2012]. Available at http://www.cdc. gov/niosh/docs/2003-154/pdfs/1501.pdf

28. American Conference of Governmental Industrial Hygienists. ACGIH TLVs and BEIs for chemicals substances, physical agents and biological exposure indices. Cincinnati: ACGIH; 2008.

29. Gericke C, Hanke B, Beckmann G, Baltes MM, Kühl KP, Neubert D. Multicenter field trial on possible health effects of toluene. III. Evaluation of effects after long-term exposure. Toxicology 2001;168:185-209.

30. Wilcosky TC, Simonsen NR. Solvent exposure and cardiovascular disease. Am J Ind Med 1991;19:569-86.

31. Xiao JQ, Levin SM. The diagnosis and management of solvent-related disorders. Am J Ind Med 2000;37:44-61.

32. Matanoski GM, Tao XG. Styrene exposure and ischemic heart disease: a case-cohort study. Am J Epidemiol 2003;158:988-95.

33. Hewitt JB, Tellier L. Risk of adverse outcomes in pregnant women exposed to solvents. J Obstet Gynecol Neonatal Nurs 1998;27:521-31. 
34. Leong PK, Yang LE, Landon CS, McDonough AA, Yip KP. Phenol injury-induced hypertension stimulates proximal tubule $\mathrm{Na}+/ \mathrm{H}+$ exchanger activity. Am J Physiol Renal Physiol 2006;290:F1543-50.

35. Leung LC, Sung RY, So HK, Wong SN, Lee KW, Lee KP, Yam MC, Li SP, Yuen SF, Chim S, Chan KK, Luk D. Prevalence and risk factors for hypertension in Hong Kong Chinese adolescents: waist circumference predicts hypertension, exercise decreases risk. Arch Dis Child 2011;96:804-9.
36. Cook NR, Cutler JA, Obarzanek E, Buring JE, Rexrode KM, Kumanyika SK, Appel LJ, Whelton PK. Long term effects of dietary sodium reduction on cardiovascular disease outcomes: observational follow-up of trials of hypertension prevention (TOHP). BMJ 2007;334:885-92.

37. Teichman RF, Fallon F, Brandt-Rauf PW. Health effects on workers in the pharmaceutical industry: a review. J Soc Occup Med 1988;38:55-7. 
Sažetak

\section{UTJECAJ IZLOŽENOSTI MJEŠAVINI ORGANSKIH OTAPALA NA KRVNI TLAK NEPUŠAČICA KOJE RADE U FARMACEUTSKOJ TVRTKI}

Neka su istraživanja pokazala da izloženost industrijskim otapalima može utjecati na krvni tlak. U ovom smo istraživanju nastojali ispitati utjecaj mješavine organskih otapala na krvni tlak žena koje rade u farmaceutskoj tvrtki u Iranu. Četiristo trideset i tri žene bile su uključene u istraživanje. Žene koje rade u pakirnicama (G1) nisu bile izložene mješavini organskih otapala, žene koje rade u novim laboratorijskim jedinicima (G2) bile su izložene dozvoljenoj granici mješavine, a žene u starim laboratorijskim jedinicama (G3) bile su izložene količini mješavine koja je viša od dozvoljene granične vrijednosti. Usporedili smo sistolički i dijastolički krvni tlak (eng. systolic blood pressure, krat. SBP i eng. diastolic blood pressure, krat. DBP) i prevalenciju hipertenzije i prehipertenzije između navedenih skupina. Otkrili smo značajnu razliku u vrijednostima SBP-a i prevalencije prehipertenzije $(\mathrm{p}<0,001)$ i $(\mathrm{p}<0,05)$ hipertenzije između skupina G2 i G3, te kontrolne skupine (G1), ali se vrijednosti za DBP nisu značajno razlikovale. Logistička regresijska analiza pokazala je značajnu poveznicu između hipertenzije i izlaganja mješavini otapala. $U$ usporedbi s radnicama koje nisu bile izložene mješavini, omjer izgleda za nastanak hipertenzije u skupini G2 iznosio je 2,36, a u skupini G3 3. Naši rezultati pokazuju da izlaganje mješavini organskih otapala može povisiti vrijednost SBP-a i prevalencije hipertenzije i prehipertenzije kod radnika koji rade u proizvodnji lijekova. Stoga je potrebno posvetiti veću pozornost osobama koje rade u takvim okruženjima, a mjere koje bi valjalo poduzimati uključuju redovito mjerenje krvnog tlaka i provedbu preciznih i sveobuhvatnih programa za smanjenje izlaganja organskim otapalima.

KLJUČNE RIJEČI: hipertenzija, industrijska otapala, izloženost na radu

\section{CORRESPONDING AUTHOR:}

Mirsaeed Attarchi, MD

Occupational Medicine Department, School of Medicine

Tehran University of Medical Sciences, Tehran, Iran

E-mail:drmsattarchi@gmail.com 